\title{
PEMBELAJARAN TEMATIK BAGI ANAK BERKEBUTUHAN KHUSUS DI SEKOLAH LUAR BIASA KELAS RENDAH
}

\author{
Sukadari \\ Program Pasca Sarjana \\ Universitas PGRI Yogyakarta \\ E-mail: sukadari@gmail.com
}

\begin{abstract}
Abstrak
Pembelajaran tematik adalah pembelajaran dalam bentuk tema dengan beberapa mata pelajaran yang disajikan dalam satu wadah terpadu baik secara individu maupun kelompok. Di Sekolah Luar Biasa (SLB) pada kelas rendah dengan pembelajaran yang terpisah memunculkan dampak tingginya angka mengulang kelas dan putus sekolah, maka pembelajaran tematik sangat penting diterapkan di Sekolah Luar Biasa (SLB) untuk mengaplikasikan dunia nyata di sekitar kehidupan siswa. Dalam pembelajaran tematik ini siswa Sekolah Luar Biasa (SLB) dapat memahami konsep-konsep yang mereka pelajari melalui pengalaman langsung dan menghubungkannya dengan konsep lain yang berkaitan sehinggatujuan pembelajaran tematik bagi Anak Berkebutuhan Khusus (ABK) dapat tercapai.
\end{abstract}

Kata kunci: pembelajaran tematik, anak berkebutuhan khusus, sekolah luar biasa

\begin{abstract}
Thematic learning is learning based on a type of selected theme that includes several subjects presented as one within an integrated space both for individual or groups. At Special Needs School (SLB) especially lower grades, separated learning usually results in high percentage of grade retention and drop outs; as such thematic learning is vital to be implemented in SLB to accustom students to the real world around them. In such thematic learning style, SLB students can learn to comprehend various concepts that they learn from direct experience and connect this with other relevant concepts and therefore the purpose of thematic learning for children with special needs can be adequately fulfilled.
\end{abstract}

Keywords: thematic learning, children with special needs, special needs school (slb).

\section{Info Artikel}

Diterima Februari 2020, disetujui Maret 2020, diterbitkan Juni 2020 


\section{PENDAHULUAN}

Kurikulum 2013 sebagai pengganti kurikulum lama yaitu Kurikulum Tingkat Satuan Pendidikan (KTSP) merupakan penyempurnaan kurikulum lama dan diharapkan pelaksanaannya dapat mencapai tujuan yang diinginkan. Kurikulum 2013 bertujuan untuk mempersiapkan manusia Indonesia agar memiliki kemampuan hidup sebagai pribadi dan warga negara yang beriman, produktif, kreatif, innovatif, dan afektif serta mampu berkontribusi pada kehidupan bermasyarakat, berbangsa, bernegara, dan peradaban dunia.

Peserta didik yang berada pada SLB (Sekolah Luar Biasa) kelas awal satu, dua, dan tiga berada pada rentangan usia dini. Pada usia tersebut seluruh aspek perkembangan kecerdasan seperti IQ, EQ, dan SQ tumbuh dan berkembang sangat luar biasa (Kepala Pusat Kurikulum Badan Penelitian dan Pengembangan Depdiknas, 2007)

Pada saat pelaksanaan kegiatan pembelajaran di SLB (Sekolah Luar Biasa) kelas I - III untuk setiap mata pelajaran dilakukan secara terpisah, misalnya IPA 2 jam pelajaran, IPS 2 jam pelajaran, dan Bahasa Indonesia 2 jam pelajaran. Dalam pelaksanaan kegiatannya dilakukan secara murni mata pelajaran yaitu hanya mempelajari standar kompetensi dan kompetensi dasar yang berhubungan dengan mata pelajaran itu. Sesuai dengan tahapan perkembangan anak yang masih melihat segala sesuatu sebagai suatu keutuhan (holistik), pembelajaran yang menyajikan mata pelajaran secara terpisah akan menyebabkan kurang mengembangkan anak untuk berpikir holistik dan membuat kesulitan bagi peserta didik, pelaksanaan pembelajaran yang terpisah, muncul permasalahan pada SLB kelas awal (I, II, dan III) antara lain adalah tingginya angka mengulang kelas dan putus sekolah. Angka mengulang kelas dan angka putus sekolah peserta didik kelas I SLB jauh lebih tinggi dibandingkan dengan kelas yang lain. Data Direktorat PKLK (2009/2010) memperlihatkan bahwa angka mengulang kelas satu sebesar 11,6\% sementara pada kelas dua 7,51\%, kelas tiga $6,13 \%$, kelas empat 4,64\%, kelas lima 3,1\%, dan kelas enam 0,37\%. Pada tahun yang sama angka putus sekolah kelas satu sebesar 4,22\%, masih jauh lebih tinggi jika dibandingkan dengan kelas dua $0,83 \%$, kelas tiga 2,27\%, kelas empat 2,71\%, kelas lima $3,79 \%$ dan kelas enam $1,78 \%$.

Pada saat ini hanya sedikit peserta didik kelas satu tingkat dasar yang mengikuti pendidikan prasekolah sebelumnya, tahun $2009 / 2010$ tercatat $12,61 \%$ atau 1.583 .467 
peserta didik usia 4 - 6 tahun yang masuk Taman Kanak-kanak, dan kurang dari 5\% peserta didik berada pada pendidikan prasekolah lain.

Permasalahan tersebut menunjukkan bahwa kesiapan sekolah sebagian besar peserta didik kelas awal SLB (Sekolah Luar Biasa) reguler di Indonesia cukup rendah. Sementara itu, hasil penelitian menunjukkan bahwa peserta didik yang telah masuk Taman Kanak-kanak memiliki kesiapan bersekolah lebih baik dibandingkan dengan peserta didik yang tidak mengikuti pendidikan Taman Kanak-kanak. Selain itu, perbedaan pendekatan, model, dan prinsip-prinsip pembelajaran antara kelas satu dan dua SLB (Sekolah Luar Biasa) dengan pendidikan pra sekolah dapat juga menyebabkan peserta didik yang telah mengikuti pendidikan pra sekolah pun dapat saja mengulang kelas atau bahkan putus sekolah.

Pembelajaran pada kelas awal SLB (Sekolah Luar Biasa) yakni kelas satu, dua dan tiga lebih sesuai jika dikelola dalam pembelajaran terpadu melalui pendekatan pembelajaran tematik. Untuk memberikan gambaran tentang pembelajaran tematik yang dapat menjadi acuan dan contoh konkret, disiapkan model pembelajaran tematik untuk SLB kelas I hingga kelas III.

Kurikulum tahun 2013 mengakomodir keseimbangan antara soft skills dan hard skills yang meliputi aspek kompetensi sikap, ketrampilan, dan pengetahuan. Kompetensi dikembangkan melalui pembelajaran tematik terpadu yang dilaksanakan dengan pendekatan sains. Pada kurikulum 2013 pembelajaran tematik terpadu diberlakukan diseluruh kelas di sekolah dasar luar biasa, yang meliputi seluruh mata pelajaran yang disajikan secara terpadu dengan tema sebagai pemersatu. Namun kenyataannya belum semua guru yang mengajar di SLB memiliki pengalaman mengajar menggunakan pendekatan pembelajaran tematik, khususnya guru yang mengajar di kelas tinggi (kelas IV - VI), padahal kurikulum 2013 sudah memberlakukan pembelajaran tematik disemua kelas. Oleh karena itu, pengetahuan tentang pengelolaan pembelajaran tematik terpadu sangat diperlukan bagi semua guru yang mengajar di SLB kelas awal adalah anak yang berada pada rentangan usia dini. Masa usia dini ini merupakan masa yang pendek tetapi merupakan masa yang sangat penting bagi kehdupan seseorang. Oleh karena itu, pada masa ini seluruh potensi yang dimiliki anak perlu didorong sehingga akan berkembang secara optimal. 
Perkembangan emosi anak usia 6 - 8 tahun antara lain anak telah dapat mengekspresikan reaksi terhadap orang lain, telah dapat mengontrol emosi, sudah mampu berpisah dengan orang tua dan telah mulai belajar tentang benar dan salah. Untuk perkembangan kecerdasannya anak usia kelas awal SLB ditunjukkan dengan kemampuannya dalam melakukan mengelompokkan obyek, berminat terhadap angka dan tulisan, meningkatnya perbendaharaan kata, senang berbicara, memahami sebab akibat dan berkembangnya pemahaman terhadap ruang dan waktu.

Pemerintah pada beberapa tahun lalu telah mengeluarkan kebijakan tentang otonomi daerah. Kebijakan ini antara lain memberi ruang gerak yang luas kepada lembaga pendidikan khususnya sekolah dasar maupun SLB tingkat dasar dalam mengelola sumber daya yang ada, dengan cara mengalokasikan seluruh potensi dan prioritas sehingga mampu melakukan terobosan-terobosan sistem pembelajaran yang lebih inovatif dan kreatif. Salah satu upaya kreatif dalam melaksanakan pembelajaran yang menggunakan kurikulum berbasis kompetensi di SLB tingkat dasar adalah melakukan pembelajaran tematik. Pembelajaran model ini akan lebih menarik dan bermakna bagi anak karena model pembelajaran ini menyajikan tema-tema pembelajaran yang lebih aktual dan kontekstual dalam kehidupan sehari-hari. Pelaksanaan pembelajaran tematik di Sekolah Luar Biasa tentunya memberikan berbagai implikasi baik dari segi guru, siswa, sarana dan prasarana sampai kepada proses pembelajarannya (Abdul Majid, 2014).

\section{HASIL DAN PEMBAHASAN}

\section{Tahapan Penerapan Pembelajaran Tematik}

\section{Tahap Pendahuluan}

Pada tahapan ini, guru harus berupaya menciptakan suasana belajar yang kondusif agar para peserta didik bisa memusatkan konsentrasi mereka terhadap kegiatan pembelajaran tematik. Artinya tahapan ini tidak ubahnya sebagai pengondisian awal para peserta didik agar mereka dapat fokus mengikuti proses pembelajaran tematik dengan baik dan benar.

Tetapi, biasanya anak kelas 1 dan 2 SLB (Sekolah Luar Biasa) masih malu mengungkapkan pengalamannya seputar dunia keluarga. Atas dasar itu, guru harus mempunyai kreativitas agar bisa menggali pengalaman siswa mengenai tema yang akan 
disajikan. Hal ini bisa dilakukan dengan beberapa cara sebagai berikut.
a. Bercerita
b. Kegiatan fisik/ jasmani
c. Menyanyi
d. Membaca puisi tentang keluarga
e. Menampilkan gambar yang menceritakan tentang keluarga

Dengan cara-cara semacam itu, maka para peserta didik akan mudah terpancing untuk bertanya, bercerita, dan memberi tanggapan. Kemudian dari sanalah guru akan mampu menggali pengalaman para peserta didiknya mengenai pengalaman seputar tema (Luky Indrono, 2013).

\section{Tahap Kegiatan Inti}

Kegiatan inti merupakan kegiatan pokok dalam pembelajaran. Dalam kegiatan inti dilakukan pembahasan terhadap tema dan subtema melalui berbagai kegiatan belajar dengan menggunakan multi metode dan media sehingga siswa mendapatkan pengalaman belajar yang bermakna. Pada waktu penyajian dan pembahasan tema, guru dalam penyajiannya sehendaknya lebih berperan sebagai fasilitator. Selain itu, guru harus pula mampu berperan sebagai model pembelajaran yang baik bagi siswa. Artinya guru secara aktif dalam kegiatan belajar berkolaborasi dan berdiskusi dengan siswa dalam mempelajari tema atau sub tema yang sedang dipelajari. Peran inilah sebagai suatu aktivitas mengorganisasi dan mengatur lingkungan sebaik-baiknya dan menghubungkannya dengan anak sehingga terjadi proses belajar. Dengan demikian, pada langkah kegiatan inti guru menggunakan strategi pembelajaran dengan upaya menciptakan lingkungan belajar sedemikian rupa agar murid aktif mempelajari permasalahan berkenaan dengan tema atau sub-tema.

Pada tahapan ini pula, guru mulai menyajikan tema dan berbagai strategi atau metode yang bervariasi. Bahkan dalam penyajian tema pembelajaran, ia juga bisa melakukannya secara kelompok kecil, individual (perorangan), atau klasikal (Luky Indrono, 2013)

\section{Tahap Kegiatan Penutup}

Tahapan yang terakhir yang harus dilkukan oleh guru dalam pembelajaran 
tematik adalah penutup. Dalam tahapan ini, tugas guru adalah menenangkan para peserta didiknya yang telah mengikuti semua proses pembelajaran dari awal hingga akhir. Kegiatan akhir dapat diartikan sebagai kegiatan yang dilakukan oleh guru untuk mengakhiri pelajaran dengan maksud untuk memberikan gambaran menyeluruh tentang apa yang telah dipelajari siswa serta keterkaitannya dengan pengalaman sebelumnya, mengetahui tingkat keberhasilan siswa serta keberhasilan guru dalam pelaksanaan proses pembelajaran.

Dalam tahapan penutup adalah guru harus melakukan beberapa hal pokok berikut:

a. Menyimpulkan pembelajaran yang telah dilakukan dari awal hingga akhir, baik dari jalannya pembelajaran, kendala, maupun hal-hal yang terjadi selama pembelajaran berlangsung.

b. Mengungkapkan hasil pembalajaran tematik apa adanya, kurang atau pun lebih, baik dalam bentuk angka-angka, nilai, maupun pandangan guru secara lisan.

c. Memberi kesempatan kepada para siswanya untuk mengomentari seputar pembelajaran tematik yang telah dilakukan bersama mengungkapkan segala keluhannya, atau pertanyaan-pertanyaan berkaitan dengan pembelajaran yang baru saja dilakukannya.

d. Memberi nasihat dan pesan-pesan moral kepada siswa, bukan hanya yang berkaitan dengan tema pembelajaran, tetapi juga hal lain yang dianggap penting, seperti anjuran rajin belajar, nasihat menjadi anak yang baik, rajin menabung, patuh kepada guru dan kedua orang tua, dan lain sebagainya.

Implikasi diterbitkannya Peraturan Pemerintah Nomor 32 tentang Perubahan atas Peraturan Pemerintah Nomor 19 tahun 2005 tentang Standar Nasional Pendidikan ialah perubahan model pendekatan pembelajaran yang dilakukan di Sekolah Luar Biasa. Pendekatan pembelajaran tersebut adalah pendekatan pembelajaran tematik terpadu atau yang seringkali disebut sebagai tematik integratif.

Pembelajaran tematik terpadu di Sekolah Luar Biasa merupakan pendekatan pembelajaran yang mengintegrasikan berbagai kompetensi dari berbagai mata pelajaran dalam berbagai tema. Pendekatan pembelajaran ini digunakan untuk seluruh kelas pada Sekolah Luar Biasa. Pembelajaran dengan pendekatan tematik ini mencakup seluruh kompetensi mata pelajaran yaitu: PPKn, Bahasa Indonesia, IPA, IPS, Matematika, 
Pendidikan Jasmani Olahraga dan Kesehatan, Seni Budaya dan Prakarya kecuali mata pelajaran Pendidikan Agama dan Budi Pekerti. Kompetensi mata pelajaran IPA pada kelas I - III dintegrasikan pada mata pelajaran Bahasa Indonesia dan Matematika, sedangkan untuk mata pelajaran IPS diintegrasikan ke mata pelajaran Bahasa Indonesia, PPKn dan Matematika. Kompetensi dasar IPA dan IPS di kelas IV - VI masing-masing berdiri sendiri.

Pembelajaran tematik merupakan salah satu model pembelajaran terpadu yang menggunakan tema untuk mengaitkan beberapa mata pelajaran sehingga dapat memberikan pengalaman bermakna bagi siswa. Pembelajaran terpadu didefinisikan sebagai pembelajaran yang menghubungkan berbagai gagasan, konsep, keterampilan, sikap, dan nilai, baik antar mata pelajaran maupun dalam satu mata pelajaran. Pembelajaran tematik memberi penekanan pada pemilihan suatu tema yang spesifik yang sesuai dengan materi pelajaran, untuk mengajar satu atau beberapa konsep yang memadukan berbagai informasi.

Pembelajaran tematik menekankan pada keterlibatan siswa secara aktif dalam proses pembelajaran, sehingga siswa dapat memperoleh pengalaman langsung dan terlatih untuk dapat menemukan sendiri berbagai pengetahuan yang dipelajarinya. Teori pembelajaran ini dimotori para tokoh Psikologi Gestalt, termasuk Piaget yang menekankan bahwa pembelajaran haruslah bermakna dan berorientasi pada kebutuhan dan perkembangan anak.

Pembelajaran tematik lebih menekankan pada penerapan konsep belajar sambil melakukan sesuatu (learning by doing). Oleh karena itu, guru perlu mengemas atau merancang pengalaman belajar yang akan mempengaruhi kebermaknaan belajar siswa. Pengalaman belajar yang menunjukkan kaitan unsur-unsur konseptual menjadikan proses pembelajaran lebih efektif. Kaitan konseptual antar mata pelajaran yang dipelajari akan membentuk skem, sehingga siswa akan memperoleh keutuhan dan kebulatan pengetahuan.

Pembelajaran tematik memiliki ciri khas, antara lain seperti berikut.

a. Pengalaman dan kegiatan belajar relevan dengan tingkat perkembangan dan kebutuhan anak usia sekolah dasar.

b. Kegiatan-kegiatan yang dipilih dalam pelaksanaan pembelajaran tematik bertolak dari minat dan kebutuhan siswa. 
c. Kegiatan belajar dipilih yang bermakna dan berkesan bagi siswa sehingga hasil belajar dapat bertahan lebih lama.

d. Memberi penekanan pada keterampilan berpikir siswa

e. Menyajikan kegiatan belajar yang bersifat pragmatis sesuai dengan permasalahan yang sering ditemui peserta didik dalam lingkungannya.

f. Mengembangkan keterampilan sosial siswa, seperti kerjasama, toleransi, komunikasi, dan tanggap terhadap gagasan orang lain.

\section{Contoh Karakteristik Mata Pelajaran di SLB}

a. Mata Pelajaran PPKn

Di SLB mata pelajaran PPKn tidak diajarkan tersendiri tetapi diintegrasikan dengan mata pelajaran yang lain melalui pembelajaran tematik terpadu.

b. Mata Pelajaran Matematika

Cakupan materi matematika di SLB meliputi bilangan asli, bulat, pecahan, geometri dan pengukuran sederhana, dan statistika sederhana serta kompetensi matematika dalam mendukung pencapaian kompetensi lulusan SLB ditekankan pada :

c. Menunjukkan sikap posiitf bermatematika: logis, kritis, cermat dan teliti, jujur, bertanggung jawab, dan tidak mudah menyerah dalam menyelesaikan masalah, sebagai wujud implementasi kebiasaan dalam inkuiri dan eksplorasi matematika

d. Memiliki rasa ingin tahu, percaya diri, dan ketertarikan pada matematika, yang terbentuk melalui pengalaman belajar.

e. Menghargai perbedaan dan dapat mengidentifikasi kemiripan dan perbedaan berbagai sudut pandang

f. Mengklarifikasi berbagai benda berdasar bentuk, warna, serta alasan pengelompokannya

g. Mengidentifikasi dan menjelaskan informasi dari komponen, unsur dari benda gambar atau foto dalam kehidupan sehari-hari

h. Menjelaskan pola bangun dalam kehidupan sehari-hari dan memberikan dugaan kelanjutannya berdasarkan pola berulang.

i. Memahami efek penambahan dan pengambilan benda dari kumpulan objek serta memahami penjumlahan dan pengurangan bilangan asli, bulat, dan pecahan

j. Menggunakan diagram, gambar, ilustrasi, model konkret atau simbolik dari suatu 
masalah dalam penyelesaian masalah

k. Memberikan interprestasi dari sebuah sajian informasi/data

Pembelajaran tematik sebagai suatu konsep dapat diartikan sebagai pendekatan pembelajaran yang melibatkan beberapa mata pelajaran untuk memberikan pengalaman yang bermakna bagi siswa. Dikatakan bermakna karena dalam pembelajaran tematik, siswa akan memahami konsep-konsep yang mereka pelajari melalui pengalaman langsung dan menghubungkannya dengan konsep lain yang sudah mereka pahami.

Pembelajaran tematik merupakan suatu pendekatan yang berorientasi pada praktik pembelajaran yang sesuai dengan kebutuhan perkembangan anak. Pembelajaran ini berangkat dari teori pembelajaran yang menolak proses latihan/ hafalan (drill) sebagai dasar pembentukan pengetahuan dan struktur intelektual anak. Teori belajar ini dimotori oleh para tokoh psikologi Gestalt, (termasuk teori Piaget) yang menekankan bahwa pembelajaran itu haruslah bermakna dan menekankan juga pentingnya Program pembelajaran yang berorientasi kebutuhan perkembangan anak.

Pembelajaran tematik adalah sebuah pembelajaran yang dikemas ke dalam bentuk tema yang melibatkan beberapa mata pelajaran yang disajikan dalam satu wadahyang terpadu. Pembelajaran tematik merupakan salah satu dari model-model pembelajaran yang dipadukan/ terpadu (integrated instruction) yang merupakan suatu sistem pembelajaran yang menekankan siswa, baik secara individual maupun secara kelompok, aktif menggali dan menemukan konsep serta prinsip-prinsip keilmuan secara holistik, bermakna, dan autentik, sehingga dalam kegiatan pembelajaran, siswa secara aktif diarahkan untuk terlibat.

Dalam pembelajaran tematik ini, siswa SLB diharapkan dapat memahami konsep-konsep yang mereka pelajari melalui pengalaman langsung dan menghubungkannya dengan konsep lain yang berkaitan. Dengan pembelajaran tematik ini.

Oleh karena itu, dari keunggulan yang disebutkan di atas, pembelajaran tematik sangat penting untuk diterapkan di SLB, mengapa demikian? Karena pembelajaran ini memiliki banyak nilai dan manfaat,yang diantaranya adalah : (1) penggabungan beberapa kompetensi dasar dan indikator dapat terjadi tumpang tindih materi sehingga dapat dikurangi dan bahkan dapat dihilangkan; (2) isi/materi pelajaran lebih berperan sebagai sarana atau alat, sehingga siswa dapat melihat hubungan-hubungan yang lebih 
bermakna; (3) siswa lebih fokus dan tidak terpecah-pecah, karena materi yang disajikan lebih terpadu, sehingga penguasaan materi pelajaran akan materi yang disajikan lebih terpadu, sehingga penguasaan materi pelajaran akan semakin baik dan meningkat; dan (4) memperkaya transfer belajar (transfer of learning) siswa, karena isi pelajaran diterapkan dari dunia nyata di sekitar kehidupan siswa.

\section{Pembelajaran Tematik Terpadu Dalam Kurikulum 2013}

Pembelajaran tematik terpadu yang diterapkan di SLB pada satuan pendidikan SDLB dalam kurikulum 2013 berlandaskan pada Permendikbud Nomor 65 tahun 2013 tentang Standar Proses Pendidikan Dasar dan Menengah yang menyebutkan, bahwa sesuai dengan Standar Kompetensi Lulusan dan Standar Isi, maka prinsip pembelajaran yanbg digunakan 2013 pada SLB dilakukan melalui pembelajaran dengan pendekatan tematik terpadu dari kelas I sampai kelas VI.

\section{Karakteristik yang Dimiliki Anak-anak Usia SLB di tingkat Dasar}

Karakteristik yang dimiliki anak-anak usia SLB sebagai berikut

a. Senang bergerak; berbeda dengan orang dewasa yang betah duduk berjam-jam anakanak usia SLB lebih senang bergerak. Anak-anak usia ini dapat duduk dengan tenang maksimal sekitar 30 menit.

b. Senang bermain; dunia anak memang dunia bermain yang penuh kegembiraan, demikian juga dengan anak-anak usia sekolah dasar, mereka masih sangat senang bermain, apalagi anak-anak SLB kelas rendah.

c. Senang melakukan sesuatu secara langsung; anak-anak usia SLB akan lebih mudah memahami pelajaran yang diberikan guru jika ia dapat mempraktikkan sendiri secara langsung pelajaran tersebut.

d. Senang bekerja dalam kelompok; pada usia SLB, anak-anak mulai intens bersosialisi, pergaulan dengan kelompok sebaya akan membuat anak usia SLB bisa belajar banyak hal, misalnya setia kawan, bekerja sama, dan bersaing secara sehat.

Berdasarkan karakteristik anak kelas awal tersebut, maka pendidik perlu menyiapkan berbagai aktivitas/kegiatan yang cocok dan sesuai. Berbagai kegiatan yang dapat dilakukan sesuai dengan tahapan perkembangan anak kelas awal (kelas I - III)

Prinsip-prinsip Pembelajaran Tematik Tingkat SLB 
Prinsip dalam penggalian tema seperti berikut:

a. Tema tidak terlalu luas sehingga mudah untuk memadukan mata pelajaran

b. Bermakna, sehingga bisa digunakan sebagai berkal bagi siswa untuk belajar selanjutnya

c. Sesuai dengan tingkat perkembangan siswa

d. Mampu menunjukkan sebagian besar minat siswa

e. Mempertimbangkan peristiwa otentik (riil)

f. Sesuai dengan kurikulum dan harapan masyarakat

g. Mempertimbangkan ketersediaan sumber belajar

\section{KESIMPULAN}

a. Kurikulum 2013 untuk SLB (Sekolah Luar Biasa) melaksanakan pembelajaran Tematik Terpadu dan prosesnya dengan pendekatan saintifik. Penerapan pembelajaran tematik terpadu dengan pendekatan saintifik membawa implikasi perubahan dalam pembelajaran di SLB. Perubahan itu mengakibatkan perubahan buku siswa, buku guru, sistem penilaian, pelaksanaan program remedial dan pengayaan, dan sebagainya.

b. Peserta didik pada sekolah luar biasa (SLB) yang saat ini masih ada yang dilaksanakan secara terpisah digantikan dengan sistim pendidikan pembelajaran tematik sesuai dengan kurikulum 2013

c. Tahapan penerapan pembelajaran tematik dilaksanakan dengan bersungguh-sungguh mulai dari tahap pendahuluan, kegiatan inti dan penutup serta memberi makna dalam pembelajaran karena dengan tematik siswa mempu memahami konsep dan melalui pengalaman langsung dapat menghubungkan dengan konsep yang sudah difahami.

\section{DAFTAR PUSTAKA}

Anderson, L.W., and David R. Krathwohl, D.R. (2001). A Taxonomy for Learning.

Anonim. (2013). Panduan Teknis Penyusunan RPP di Sekolah Dasar. Direktorat Pembinaan Sekolah Dasar. Jakarta.

Departemen Pendidikan Nasional. (2005). Pembelajaran Tematik Kelas Awal SD/SLB/MI. Jakarta: Pusat Kurikulum Badan Penelitian dan Pengembangan 
Depdikbud. (2013). Kurikulum 2013 PLB. Jakarta: Direktorat Pembinaan Pendidikan Khusus dan Layanan Khusus

Depdikbud. (2014). Pedoman Pembelajaran Tematik Terpadu Lampiran III Permen Nomor 57 Tahun 2014. Jakarta.

Depdikbud. (2014). Pendidikan Khusus dan Layanan Khusus. Jakarta. Pendidikan Dasar Direktorat Jenderal Pendidikan Dasar. Kemendikbud

Direktorat Pendidikan Luar Biasa. (2003). Pengembangan Kurikulum dalam Pendidikan Terpadu/Inklusi. Jakarta: Ditjen Dikdasmen.

Dyer,J., Gregersen, H., and Christensen, C. M. (2011). The Innovators's DNA: Mastering the Five Skills of Distruptive Innovators. Boston: Harvard Bussiness Review Press.

Johnson, E.B. (2009). Contextual Teaching \& Learning (Terjemahan). Bandung: Penerbit MLC.

Kementerian Pendidikan dan Kebudayaan. (2015). Buku Guru Tema 1 Diriku, Buku Tematik Terpadu Kurikulum 2013. Jakarta.

Kirk, S. A and Gallangher, J. J. (1986). Pendidikan Luar Biasa. Ahli bahasa oleh Moh. Amin, 1990. Jakarta: Benica.

Kustawan, D., dan Lisnawati, Y. (2014). Program Kekhususan, Program Pengembangan Diri untuk Peserta Didik Tunagrahita. Direktorat Pembinaan.

Lela, H.P. (2015). Pembelajaran Pengembangan Diri Bagi Anak Tunagrahita. Modul Diklat Pasca UKG Jenjang Lanjut. Bandung. PPPPTK TK PLB

Pusat Kurikulum dan Pembukuan (2015). Pedoman Pembelajaran Tematik Terpadu. Jakarta: Pusat Kurikulum dan Perbukuan, Balitbang Kemdikbud

Pusat Kurikulum dan Perbukuan. (2015). Pedoman Pembelajaran. Jakarta: Pusat Kurikulum dan Perbukuan, Balitbang Kemdikbud

Pusat Pengembangan Tenaga Kependidikan. (2013). Bahan Ajar Pengelolaan Pembelajaran Tematik Terpadu. Jakarta: Pusat Pengembangan Tenaga Kependidikan, Badan Pengembangan Sumber Daya Manusia dan Kebudayaan dan Penjaminan Mutu Pendidikan, Kementerian Pendidikan dan Kebudayaan.

Republik Indonesia. (2003). Undang-undang Nomor 20 tentang Sistem Pendidikan Nasional. Jakarta: Kementerian Pendidikan Nasional

Rochyadi, H. (2012). Modul Program Kekhususan bagi Anak Tunagrahita. Bandung. PPPTK TK \& PLB.

Salim, Gunarhadi, dan Anwar. (2015). Pembelajaran Terdiferensiasi Bagi Anak Berkebutuhan Khusus di Sekolah Inklusif. Surakarta: UNS Press. 
Sukadari. (2020). Model Pembelajaran Tematik SBK (Siswa Berkebutuhan Khusus) Kelas Awal di Sekolah Luar Biasa, Yogyakarta, Penerbit: Kanwa Publiser.

Trianto. (2012). Mengembangkan Model Pembelajaran Tematik. Jakarta. Penerbit: Prestasi Pustakarya.

Widyastono, H. (2015). Bahan paparan Kebijakan Pengembangan Kurikulum 2013. Jakarta: Pusat Kurikulum dan Perbukuan, Balitbang Kemdikbud. 